\title{
Indonesia's Role in Myanmar's Democratic Transition
}

\author{
M. Adian Firnas \\ Lecturer at Faculty of Social and Political Sciences UIN Jakarta \\ Student of Doctoral Programme at Departement of Political Science, University of Indonesia \\ adian.firnas@uinjkt.ac.id
}

\begin{abstract}
This paper aims to find out Indonesia's role as one of the influential countries in ASEAN in Myanmar's democratic transition. Since 1990, Myanmar has been getting the world's attention for the international isolation due to the sanctions imposed by the West because of the annulment of the 1990 election results by the military junta and human rights abuses against its people.

The political transformation in Indonesia in 1998 made Indonesia one of the largest democracies in the world. This position, of course, gives influence to the development of regional democracy, especially how Indonesia plays its role on this issue. For example is to implement the Bali Democracy Forum, which aims to strengthen democracy through discussions between countries.

Eventually, the political transformation also took place in Myanmar. The country decided to make a political transition by conducting elections in 2010. This election was the first since 1990. Since then political openness has begun to be implemented in this country. Myanmar elected as the Chair of ASEAN 2014 and shows the seriousness to make a political transition amid criticism that continues to be addressed to the country.Indonesian responses this transformation by supporting Myanmar's efforts to accelerate the process of reform and democratization.
\end{abstract}

\section{Keywords- Transition, democratization, bilateral cooperation}

\section{INTRODUCTION}

Myanmar is a country whose military tradition remains strong in its internal political structure. Since 1962 until now the military is still an influential political force in the political, social and economic life of the people of Myanmar.

The role of military can be traced back to the 1990s when the military took over the power of the winning NLD and conducted human rights abuses in the country. Aung San Suu Kyi, who won the election, along with other pro-democracy figures, was arrested and imprisoned. In addition, the military junta then banned the political activities of its people, freedom of expression and restrained opinion. If there is any violation, the military junta did not hesitate to use the repressive means to silence the movement [1].

One of the regime's repressive cases was the brutal action of the military junta in silencing the mass demonstrations on September 26, 2007 that killed dozens and injured more than hundredsof people. This action had prompted the international community including ASEAN to pressure the military junta to apply human rights principles in solving its internal problems.

The drastic change took place in 2010, because without being preceded by a political crisis or mass action demanding a military withdrawal from politics, the military regime held its first multi-party elections in the past twenty years. The election held on 7 November 2010 is consideredas a new chapter to a democratic political transition in Myanmar, although many observers also doubt the seriousness of the military regime to run politics back to the barracks.

Surprising steps continue to be done by the military regime. In addition to making the country more open to the outside world, the regime also issued a policy to release political prisoners in accordance with the demands of the international community. The climax was when the regime freed Myanmar's democracy icon Aung San Suu Kyi from house arrest and allowed Suu Kyi to do political activities, even her Party, National League for Democracy (NLD) won the 2015 Election [3].

Indonesia has a political history similar to Myanmar. Both tried to apply liberal democracy early in their independence, but insurgency and unresolved internal political upheaval led to the emergence of authoritarian powers which later dominated the socio-political system of society. ABRI through its Dwi Function doctrine became the dominant force during the New Order period.

The winds of change blow when the reform power succeeded in forcing President Soeharto, who had ruled the country for more than 32 years, to surrender his power to BJ Habibie. Since then the reform agenda has begun, starting with the first democratic elections of 1999. Following that people's political participation was expanding and the press had their freedom. Furthermore, efforts were made to enforce human rights, bureaucratic reforms, TNI reforms that place civilian supremacy over the military, and eventually, thedirectelectionswere held at the national and local level since the year 2005. These achievements placed Indonesia as one of the largest democracies in the world. Even the United States Media, New York Times, in its report in 2014 called Indonesia as a model or role model of democracy in Southeast Asia [4]. 


\section{POLITICAL TRANSITION IN MYANMAR}

Due to the repressive stance of the military junta against the people of Myanmar, it had generated various reactions and intense pressure from the international community. The pressureresulted in the commitment of the Myanmar government to implement the values of democracy. The first step taken by the Myanmar government to demonstrate its commitment to democracywas shown by appointing General KhinNyunt as the Prime Minister in 2003. Outsiders, General KhinNyunt,is considered a moderate military, one who agrees with national reconciliation and international community involvement in thedemocratic process in Myanmar. General KhinNyunt's first task was to ensure that the process of reconciliation with opposition groups went smoothly.

Khin Nyunt showed his commitment by announcing seven steps towards democracy or known as theMyanmar's roadmap to democracy. There are seven stages formulated, as follows:

1. Reconvening of the national convention that has been adjourned since 1996.

2. After the successful holding of the national convention, step by step implementation of the process necessary for the emergence of a genuine and disciplined democratic system.

3. Drafting a new constitution in accordance withbasic principles and principles laid dawn by the national convention.

4. Adoption of the draft constitution through national referendum.

5. Holding of free and fair elections for Pyithu Hluttaws(People's assemblies) according to the new constitution.

6. Convening of Hluttaw attended by Hluttaw members in accordance with the new constitution.

7. Building a modern, developed and democratic nation by the state leaders elected by Hluttaw; and the government and other central organs formed by Hluttaw.

In accordance with the policy, the government of Myanmar immediately promised that the implementation of the convention in question wouldbe held in 2004 and 2005. However, the government failed to fulfill its promise.The failure happened because, at the first convention, the NLD as the opposition party was boycotted. While at the second convention, even though the convention could be implemented, it was considered invalid by the UN and other international societies because the conventiondid not invite the NLD party and other opposition parties.

The next step taken by the government of Myanmar after the convention was to draft the constitution. Despite a lot of polemics and rejection, the new constitutionwas successfully drafted and passed through a referendum in 2008. The rejectionshowed that there are efforts made to keep the space for the military to rule, covert and limit certaingroup of people. For instance, the prohibition for the citizen who is married to a foreigner to run as a presidential candidate.

The fifth step of the country's roadmap to democracy is to conduct the free and fair elections to form parliaments. Based on that, government set the electionsto be held in 2010 . This election had proven the seriousness of the Myanmar government to run ademocracy. Finally, the election was held on November 7, 2010, and the election results put Union Solidarity and Development Party (USDP) as the winning party of the election [5]. Although in the election NLD did not participate, in the next election NLD was able to join the election and put Aung Saan Suu Kyi inthe parliament. Currently, Aung Saan Suu Kyi has gained her political freedom and is free to travel abroad. Something he had never had in a dozen years since he was under house arrest.

\section{THE ROLE OF INDONESIA IN TRANSITION OF DEMOCRACY IN MYANMAR}

According to Desra Percaya, theDirector General for Asia Pacific and Africa Ministry of Foreign Affairs of the Republic of Indonesia, Indonesia' constitution serve as a basis of Indonesia's assistance to push the reform and democratization in Myanmar. It is a mandate for the nation, and it explicitly mentions that "indeed freedom is the right of all nations and therefore, over the world should be abolished because it is not in line with humanity and justice."[6]

Indonesia's approach to strengthening democracy in Myanmar is a persuasive approach in line with the prevailing co-existence and non-intervention principles among ASEAN countries. Ali Alatas, the former Indonesian Foreign Minister, said that the best approachto help Myanmar is through a Constructive-Engagement, by encouraging Myanmar to modify its policies through sustainable relations and quiet diplomacy, rather than isolating the country or imposing an economic sanction [7]. Adhering to these principles, Indonesia is strengthening democracy in Myanmar through dialogue and capacity building.

\section{Bilateral Dialogue between Indonesia and Myanmar}

Indonesia's influential position in the ASEAN region as well as UN support for Indonesia to contribute to democracy in Myanmar is a capital for Indonesia in playing an essentialrole in the development of democracy in Myanmar. Even Myanmar's democracy activist who is also Burma Partnership Coordinator, Khint Ohmar, thinks Indonesia can provide a real assistance to Myanmar's democracy because Indonesia's good track record of mediating conflicts in Southeast Asia and Indonesia has proven to be a country capable of smoothly transitioning democracy [8 ].

Various steps of dialogue conducted by Indonesia, among others:

1. The dialogue between President SBY and President Thein Sein. It was held on the sidelines of the ASEAN Summit series in Myanmar in 2012. During the meeting President 
Yudhoyono committed not only support the democratic issues but also to maintain the integrity of the country as well as push Myanmar's to fulfill the promise to run the democracy world. President SBY had previously done second track diplomacy by sending a letter to Burma's military leader General Than Shwee; the letter aimed to intimately build a good relationship Myanmar's in the hope that the country can also cooperate with other countries.

2. Meeting between Foreign Minister Retno Marsudi and Aung San Suu Kyi in 2016. The meeting discussed the agreement between Indonesia and Myanmar to enhance the cooperation of interfaith dialogue. This meeting was a follow-up of the commitment of both countries to improve collaboration related to good governance, human rights, and democracy.

3. Meeting of Foreign Minister Retno Marsudi and Minister of Information of Myanmar on January 25, 2017. During themeeting the two ministers discussed the cooperation on capacity building. In Myanmar's view Indonesia is a good laboratory for studying processes related to democratic transition, let alone Indonesia and Myanmar having the same history [9].

5. Meeting between Foreign Minister Retno Marsudi and State Counselor Daw Aung San Suu Kyi on September 4, 2017, in Nay Pyi Taw, Myanmar. This dialogue wasrecently held in response to the humanitarian crisis that took place in Rakhine. Indonesia sees the importance of resolving the humanitarian crisis in Rakhine as it is an essential part of strengthening the democracy especially in implementing human rights values in Myanmar. During the meeting, Indonesian Minister of Foreign Affairs submitted Indonesia's proposal called Formula $4+1$ to address the condition of Rakhine State. These four elements consist of (i) restoring stability and security; (ii) maximum restraint and non-violence; (iii) protection to all persons in the Rakhine State, regardless of race and religion; and (iv) the importance to provide immediate access to humanitarian assistance [10].

One significant achievement that Indonesia achieved in the meeting was the agreement between Indonesia and ASEAN to be involved in the distribution of humanitarian aid in Rakhine State. The Government of Myanmar led the distribution mechanism, but the process involved the ICRC and several countries including Indonesia and ASEAN.

\section{Multilateral Dialogue}

Indonesia's next approach is to establish the Bali Democracy Forum (BDF). BDF is an annual forum established during the President SBY erain December 2008. Indonesia organized this forum as a form of strategy and mission to encourage the development and promotion of democracy in Asia. BDFis an open forum that allows any country to attend it, not only Asian countries but also countries from other regions. Myanmar is one of the ASEAN countries that participate this forum [11].

Through this forum, every participating country including Myanmar works together on the exchange of experiences and best practices to encourage the strength of non-forced democracy, to grow and develop thestrength and ability from within.To date, BDF has been heldnine times. The BDF IX Forum was held in December 2016 in Denpasar, Bali.

By engaging in this forum, Myanmar is actively involved in the dialogue and dissemination of democratic without any pressure or intervention from any parties. Thisis possible because as the initiator, Indonesia still put forward the prevailing norm in ASEAN that the principle of nonintervention in regulating the relationship of the member countries.

\section{Capacity Building}

Indonesia's next step in influencing the strengthening of democracy in Myanmar is through capacity building activities in the Institute for Peace and Democracy (IPD) forum. Some of the capacity building activities undertaken by IPD for Myanmar are:

\section{The Dialogue on Leadership and Political Party Reform}

This dialogue was held on 9-10 November 2013 in Bali. Participants from Myanmar came from various institutions, including political parties, parliament members, the Myanmar Institute of Strategic \& International Studies (MISIS), Myanmar Development Resources Institute (MDRI), Myanmar Peace Center, Union Solidarity and Development Party (USDP), National League for Democracy (NLD), media and non-government organizations. The purpose of this dialogue was to provide an opportunity for delegates from Myanmar to learn Indonesia's experience in reforming political parties. Hence, they could make a comparison between the two countries and found out what should be donein theirs.

The Cooperation with the Myanmar Institute for Social and International Studies (MISIS)

On February 28, 2014, IPD visited Myanmar to follow up cooperation with MISIS to strengthen Myanmar's democracy. There were several cooperations that both countries wanted to organize together; the first one was the Election Visit Program (EVP) during the 2014 Indonesian Parliamentary and Presidential elections. Following that, the plan was to establish a support to Myanmar Election in 2015 through a dialogue addressing issues on managing conflict, developing election law, election processes, election outcomes, engaging media and civil society and other matters related to election fraud. Both countries also established the interfaith dialogue that brought Islamic and Buddhist scholars and leaders to discuss the ways to build peace and to promote democracy.

Election Visit Program (EVP) Myanmar 2015 
Responding to the second election after 2010, IDP in cooperation with Indonesian Embassy inYanggoon paid a visit during the Myanmar 2015 election. EVP team consisted of Prof. Dr. Ramlan Surbakti (Former Chairman of the Indonesian Election Commission), Mochammad Afifudin (Project Manager for People's Voter Education Network / JPPR, Indonesia), Titi Anggraini (Director of the Association for Elections and Democracy Perludem, Indonesia), Viengsavanh Philalom (Researcher of the Institute of Foreign Affairs, Laos) and Dam Thi Dao, MA (Researcher of the Department of Thailand - Myanmar Studies, Institute for Southeast Asian Studies, Vietnam Academy of Social Sciences), took part by being witnesses in several polling stations. This activity is conducted as a form of oversight from external parties to make sure that the election is carried out fairly and transparently.

\section{CONCLUSION}

The democratic transition in Myanmar is not a sudden process and an easy case, since 1962 a powerful military regime has ruled the country. Indonesia believes that democracy must come from within, without any external compulsion and in accordance withthe local values that have been the fundamental norm in the life of the people and the state. Therefore, as a country that has successfully transitioned democracy, Indonesia feels the need to promote the values of democracy through persuasion and constructive approach, not the confrontational one. Indonesia's dialogue and capacity building approach to Myanmar has had a positive influence on the strengthening of democracy there.

\section{References}

[1]. B.M. Jain, "Dynamics of Political Transition in Myanmar", Indian Journal of Asian Affairs, Vol.19, No.2 (December 2006),pp .6,

[2]. JurgenHaacke, "The Myanmar imbroglio and ASEAN : heading towards the 2010 elections, International Affairs, Vol.86,No.1 (Jan.2010), pp.153-174, .Published by:wiley on behalf of the Royal Institute of International Affairs.

[3].Internasional.kompas.com/read/2015/11/13/15061251/Partai.suu. Kyi.dinyatakanMenang.Mutlak.dalam.Pemilu.Myanmar

[4]. https;//www.nytimes.com/2014/09/05/world/asia/in-southeastasia.indonesia-become-a-role-model-for-demokracy.html,

[5]. www.kompas.com, hasilpemilu Myanmar 2010

[6]. http://jpp.go.id.peristiwa/internasional/30235-sesuai-amanatkonstitusi-indonesia-bantu-kuatkan-demokrasi-myanmar.

[7]. NazaruddinNasution, PelanggaranHakAsasiManusia di Asia Tenggara dalamKerangkaPiagamAseandanKomunitasAsean 2015, Ph.D Dissertation, SekolahPascasarjana UIN SyarifHidayatullah Jakarta, 2017.

[8]. https://m.tempo.co/read/news/2010/05/27/118250907/aktivisdemokrasi-burma-berharap-peran-indonesia-di-asean.

[9]. https://www.merdeka.com/dunia/sambangi-menlu-mnyanmaringin-belajar-demokrasi-dari-indonesia.html .

[10]. http://www.kemlu.go.id/id/berita/Pages/Menlu-RI-Serahkanusulan-Formula-41-untuk-Rakhine-State-kepada-StateCounsellor-Myanmar.aspx,

[11]. IbnuPurna, Inisiatif dan Inspirasi Demokrasi dalam Bali Democracy Forum,www.setneg.go.id/indek.php?lang,

[12]. http://www.ipd.or.id/about-ipd/who-we-are. 